\title{
Middle School Mathematics Teachers' Reflection Activities in the Context of Lesson Study
}

\author{
Erhan Bozkurt
}

Usak University, Faculty of Education, erhanb82@gmail.com

İfet Elif Yetkin-Özdemir

Hacettepe University, Faculty of Education, ozdemiry@hacettepe.edu.tr

|

The aim of this case study is to define reflection activities of a lesson study group that consisted of three middle school mathematics teachers in Usak, Turkey. In the process, the participants worked in collaboration for about 5 months to implement three study lesson practices. The data were collected through observations in the reflection processes of the study lessons. Teachers' reflection activities were analyzed based on the literature of teacher self-regulation. As a result, lesson study encouraged teachers to make detailed and reliable evaluations, controllable causal attributions, and productive inferences for their teaching.

Keywords: reflection on teaching, lesson study, middle school mathematics teaching, reflection activities, mathematics teachers

\section{INTRODUCTION}

Reflection is a process in which individuals reach conclusions about their task performances (Zimmerman, 2000). In this process, individuals activate a series of cognitive processes such as self-evaluations, causal attributions, and adaptive-defensive inferences (Pintrich, 2000; Schunk, 2001; Zimmerman, 2000). In the process of selfevaluation, individuals compare their observational data about their task performance with specific criteria (Zimmerman, 2000, 2002; Zimmerman \& Schunk, 2004). Teachers may compare their teaching performance with diverse criteria such as their previous teaching performance and different teachers' teaching performance (Çapa-Aydın \& Uzuntiryaki-Kondakçı, 2014; Yetkin-Özdemir, Gürel, Akdal \& Bozkurt, 2014). At the end of this process, teachers judge their teaching performance as successful or unsuccessful. In order to make reliable judgments, teachers must define teaching performances realistically based on their systematic observations, and then must compare with clear and compatible criteria. Otherwise, unrealistic judgments could arise from these evaluations. For instance, a lesson aimed at meaningful learning may be

Citation: Bozkurt, E., \& Yetkin-Özdemir, İ. E. (2018). Middle School Mathematics Teachers' Reflection Activities in the Context of Lesson Study. International Journal of Instruction, 11(1), 379394. https://doi.org/10.12973/iji.2018.11126a 
evaluated based solely on a superficial criterion such as attendance rates of students rather than the quality of student responses (Yetkin-Özdemir et al., 2014).

Causal attribution is defined as a person's perceptions about the causes of successfulunsuccessful task cases (Weiner, 1985; Zimmerman, 2000, 2002). Attributions influence future task performance and motivation. Individuals who attribute failure to controllable factors like "lack of effort" are more likely to show greater performance in the following tasks (Pintrich, 2000; Schunk, 2012; Simon, 1995; Zimmerman, 2002). Therefore, teachers are expected to attribute success and failure to factors that are in their control such as choosing inappropriate instructional methods (Yetkin-Özdemir et al., 2014; Yetkin-Özdemir, Gürel, Bozkurt \& Akdal, 2015).

Following these attributions, teachers make inferences about regulations they will make in the next teaching task (Çapa-Aydın \& Uzuntiryaki-Kondakçı, 2014; Yetkin-Özdemir et al., 2014). Adaptive inferences, such as trying a different teaching method are important. This is because such inferences encourage individuals to improve their task strategies or to use new and probably more effective strategies. On the other hand, defensive inferences could lead individuals to refrain from making the necessary regulations and display self-restrictive behaviors (Zimmerman, 2000, 2002; Zimmerman \& Schunk, 2004).

In the literature on reflection in teaching (for example Kwon \& Orrill, 2007; Lin, 2001; Nathan \& Knuth, 2003; Paris \& Winograd, 2001; Tursini, 2012; Zakaria \& Maat, 2010), the researchers frequently suggested that reflection activities help teachers to identify their own teaching problems and to improve their teaching practices. For example, Gabriele and Joram (2007) claimed that reflection activities encouraged math teachers' to focus more on student thinking processes (e.g., solution strategies, learning styles) in their reflection, to identify specific and clear criteria in their evaluations, and to develop positive affective reactions.

On the other hand, Zakaria and Maat (2010) observed that mathematics teachers were inability to use appropriate assessment criteria in their evaluations. Also, YetkinÖzdemir et al. (2015) reported that novice mathematics teachers frequently focused on unsuccessful teaching situations and tended to explain their failure with uncontrollable factors such as poor learning skills of students, lack of teaching material, and complexity in curriculum. These studies claimed that mathematics teachers should be forced to conduct reflection activities effectively. However, the findings of these studies were frequently obtained from interview data. In order to define teachers' reflection activities in detail and realistically, there is a necessity for studies that will observe their reflection processes in their natural teaching process. The lesson study model developed in Japan (Fernandez \& Yoshida, 2004; Stepanek, 2001; Yoshida, 1999) provides a suitable context for such studies.

During a lesson study cycle, teachers collaborate on a broad, student-centered goal (for example, improving students' self-efficacy in mathematics) called research theme. Teachers could plan a series of lessons called "study lesson" in a lesson study process. A volunteer group member practices study lesson in her/his classroom. Other group 
members participate in this lesson as observer. Then group gathers again with the aim of sharing observations about lesson (Doig \& Groves, 2011; Stepanek, Appel, Leong, Mangan \& Mitchell, 2007). In reflection process, implementer teacher shares her/his evaluations with group members first. Then other group members share their ideas about strengths and weaknesses of lesson (Doig \& Groves, 2011; Lewis, 2000; Stepanek, 2001; Stepanek et al., 2007; Takahashi \& Yoshida, 2004). After these evaluations, solution recommendation are discussed and determined (Stepanek et al., 2007). The aim of all discussion in this process is to improve teaching, not to give feedback to implementer teacher (Doig \& Groves, 2011; Saito, 2012; Takahashi \& Yoshida, 2004).

Several studies (Sponsel, 2010; Wright, 2009) provided general evidences that lesson study helps teachers to analyze their teaching critically, and concentrate students' thinking processes in reflection processes. However, when the literature was reviewed, no study was encountered examining mathematics teachers' reflection activities in detail within the context of lesson study.

\section{Objective of the Study}

The objective of this study is to identify and explain reflection activities of a group of three middle-school math teachers on their mathematics teaching tasks in a lesson study process.

\section{METHOD}

\section{Research Design}

This case study was conducted in the school year 2013-2014 with three middle school (5-8 grades) math teachers in Usak, Turkey. In case study design, a specific case (a person, a group, a program, etc.) is investigated holistically and in detail through multiple data collection methods (observation, interview, document analysis) (Creswell, 2007; Yin, 2003). The case in this study is the reflection activities of a lesson study group consisted of three middle-school math teachers who came together through the researchers for a total of 5-month period. The nature and focus of their evaluations, causal attributions, inferences for their mathematics teaching tasks in three study lesson practices, and whether and how these activities differ throughout the process were explored.

\section{Participants and the Setting}

The fact that the lesson study is a process requiring high level of responsibility and cooperation requires that teachers who agreed to participate in the study should have a say in the determination of the teachers they will work together. For this reason, the snowball sampling method was used to determine participants.

In the process of determining participants, firstly, a middle school mathematics teacher (Nihat) recognized by the first author as having the appropriate qualifications (enthusiasm, communication skills and sense of responsibility) for the study, was interviewed. Then the second participant (Mina) was determined in accordance with this teacher recommendation. Lastly, the third participant of the study was determined in 
accordance with the common recommendation of both teachers. The nicknames were used instead of their real names.

Nuray, Nihat and Mina had 8, 11 and 9 years of professional experience respectively. They had participated in a lesson study practice for the first time in their professional lives. Mina and Nihat were already acquainted with each other because they had worked in the same school. In addition, Nihat and Nuray have known each other through seminars they had already attended. However, Mina and Nuray came together for the first time through this study.

The participants believed that a successful math teacher must have sufficient knowledge of content first. In addition, to be successful, a math teacher must have a good knowledge of students, effective teaching methods, desire for self-improvement, and effective communication skills. They identified the most important challenges they have faced in their professional lives as financial impossibilities of the schools, inadequate support from the school administrations, and reluctance of the students to learn mathematics. As a mathematics teacher, Mina, Nuray and Nihat identified their most successful attributes in communication skill, classroom management and knowledge of technology respectively. On the other hand, they identified their weakest attributes as lack of classroom management and reading-research skills and inability to use different teaching methods and materials effectively.

Mina believed that students must learn mathematics in a meaningful way. She stated that use of concrete material in mathematics lesson is important. However, she could not take enough time to use material in their lessons because of high expectations of parents and students' for success in national examinations. On the other hand, Nuray believed that students must solve many math questions-problems in class and home in order to be successful in mathematics learning.

\section{Lesson Study Process}

In the lesson study process, they discussed on the most important problems they had encountered in their mathematics classes to identify their research theme first. At the end of the discussion, they identified their research theme as "student-centered education and meaningful learning". Then, they started working on study lesson practices.

In three study lesson practices, they focused on the topics of "measuring time (5th grade)", "solving first degree linear equations with one unknown" (6th grade), and "creating parallelograms" (5th grade) respectively. They collaboratively planned the lessons in three phases as warming up, main, and practicing. Each lesson was implemented by a different group member in his/her own classes. All group members participated in these lessons as an observer. Then, they met again to reflect the lessons. In the reflection processes, at first, the group members shared their opinions and recommendations respectively. Later, they watched video recordings of lessons, and made evaluations and judgments about strengths and weakness of the lessons. Finally, they drew conclusions for next study lesson process. 
Because of the participants' lack of knowledge and experience about conducting lesson study, the researchers undertook a number of responsibilities in the process:

- Guiding and providing information the group members when they need it

- Managing discussions, and encouraging group members to share their suggestions and observations with the group

- Arranging the meeting place and providing required materials (computer, projector, video camera, etc.)

- Recording the lessons with a video camera and editing the records for review in reflection meetings

\section{Data Collection Methods}

The data were collected through observations in the six reflection meetings. The first author observed all the meetings by using an open-ended observation form, which was developed by the researchers considering the literature on lesson study (for example Fernandez \& Yoshida, 2004; Stepanek et al., 2007) and teacher self-regulation (ÇapaAydın \& Uzuntiryaki-Kondakçı, 2014; Yetkin-Özdemir et al., 2014; Yetkin-Özdemir et al., 2015). In this way, the teachers' reflection activities were recorded in terms of focus (e.g. warm up activities, main activities, practicing) and nature (e.g. adaptive, defensive). In addition, all the meetings were recorded by using a video camera to observe verbal and nonverbal (gestures, facial expressions, etc.) interactions between them.

\section{Data Analysis}

In the analysis process, firstly, the video records (total of 507 minutes) were transcribed. Then, the data were coded by using a data analysis framework (see Table 1) developed by the researchers based on the literature on teachers' reflection processes (for example Çapa-Aydın, Sungur \& Uzuntiryaki, 2009; Çapa-Aydın \& Uzuntiryaki-Kondakçı, 2014; Yetkin-Özdemir et al., 2014; Yetkin-Özdemir et al., 2015).

Table 1

Data analysis framework

\begin{tabular}{ll}
\hline Themes & Explanation \\
\hline Evaluation & Comparing teaching performance with a criteria and making judgments \\
& (i.e., success or failure) \\
Scope & General assessment of lesson \\
& A phase of lesson (i.e., warming up) \\
& An activity within a lesson phase \\
Criterion & Student performances (e.g., response rate of students) \\
& The research theme \\
& Routine teaching methods/behaviors \\
& Teaching methods/behaviors in previous study lesson \\
Causal Attribution & Determining causes of successful and unsuccessful cases \\
Focus & Successful teaching situations \\
& Unsuccessful teaching situations \\
Controllability & Controllable \\
& Uncontrollable
\end{tabular}




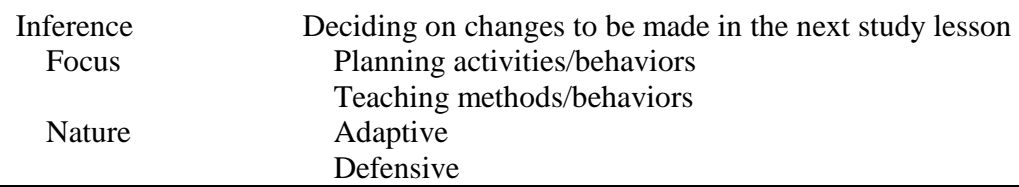

In the coding process, their reflection activities (evaluation, causal attribution, and inference) performed as a group for the different dimensions of the lessons (e.g. warming up or main activity) were coded separately. Then the relevant codes (for example, the codes related to their attribution activities) were brought together and examined in detail so that sub-concepts that identify the nature and functioning of their reflection activities were obtained. These coding workings were conducted separately for each reflection process. Following these workings, a comparative analysis of the data was conducted to identify the changes in their reflection processes.

\section{FINDINGS}

\section{Not Making Activity-Based Evaluations}

It was observed that while teachers were making evaluations in three reflection processes, similarly, they focused on the warming up, main phases, and general success situations of the lessons. They did not make any evaluation for practicing phases. In addition, they preferred to evaluate all activities in a lesson phase totally. For example, in the first reflection process that they focused on "measuring time", they preferred to evaluate the four activities in the phase of warming up totally, not separately:

Mina: ...We think that the [phase of] warming up is successful

Nihat: Yeah, I think so too

Mina: [Student] participation was good there

Nihat: Warming up was success

Mina: ...Because we took into account participation rate

Nihat: So, it was good. I think we did not have any problem in the warming up

Mina: We were able to attract students' attention

Nihat: I think so. It was good enough, yes...

(Study Lesson I-Reflection Meeting I)

\section{Making Different Evaluations with Multiple Criteria}

It was observed that while the teachers were evaluating warming up phases, they used criteria based on students' performance (responses and participation rate of the students). In addition to these criteria, they used the criteria of the research theme, routine teaching methods/behaviors, and teaching methods/behaviors in previous study lesson to evaluate the main phases and general success situations of the lessons. By using these different criteria, they made different evaluations for the same lesson dimension. For example, in the third reflection process, they defined the main activity as unsuccessful by taking into account student responses. They thought that students were not able to make a clear and correct explanation about creating parallelograms: 
Nihat: ... Now we were cluttered

Mina: Yeah, you (Nihat) said that you (the students) could use different [solution] methods in main activity

Nihat: ...Actually, many students raised their hands

Nuray: Yes, so many hands

Nihat: But why not?

Nuray: There is nothing to do

Nihat: Exactly...

(Study Lesson III-Reflection Meeting I)

However, they defined this activity as successful by comparing with their research theme. They thought that they implemented this activity in accordance with their research theme (meaningful learning and student-centered education):

Mina: ...You really tried to teach the lesson by encouraging students

to talk as much as possible

Nihat: We encouraged them to talk

Mina: You really paid attention to it

Nihat: I paid great attention, yes

Nuray: I think it (the lesson) was very successful in this sense

Nihat: Yes...

(Study Lesson III-Reflection Meeting I)

\section{Attributing Failure to a Variety of Factors}

It was observed that the teachers made attributions focused only on unsuccessful teaching situations in the first two reflection processes. However, in the third reflection process, they also made uncontrollable attributions for successful teaching situations. In their attributions focused successful, they underlined subject content and their planning activities. Teachers defined "creating parallelograms" as an advantageous subject in terms of using teaching materials because of the visual content it has. In addition, they believed that their effective planning activities also affected the success of this lesson positively:

Nuray: ... At first, we hesitated to choose this subject, but we actually made a good choice

Nihat: Yeah

Nuray: Actually, the lesson is advantageous in terms of using [teaching] materials

Nihat: Our hand was strengthened

Nuray: Yes, it was a good choice because of its visibility

(Study Lesson III-Reflection Meeting I)

Nihat: ... I think when we compare it with the first study lesson; we have made progress. You know we determined a [research] theme. We aimed meaningful learning. I believe that we have made progress towards that goal. Now we are close to our goal. Our plan was consistent with our goal...

(Study Lesson III-Reflection Meeting I) 
On the other hand, they attributed causes of the unsuccessful teaching situations to a variety of factors that were under or not under their control. The attributions of the teachers in the three reflection processes are presented in Table 2.

Table 2

Causal attributions of the teachers for unsuccessful teaching

\begin{tabular}{|c|c|c|c|c|}
\hline Controllability & Attribution & 1 & 2 & 3 \\
\hline Uncontrollabl & Lack of knowledge-experience about lesson study & $\checkmark$ & & \\
\hline \multirow[t]{7}{*}{ e } & Teaching routines & $\checkmark$ & & \\
\hline & Lack of teaching experience about subject & $\checkmark$ & & \\
\hline & Uncontrolled time losses-limited time & $\checkmark$ & $\checkmark$ & \\
\hline & Workload & $\checkmark$ & & \\
\hline & High difficulty level of the subject & & $\checkmark$ & \\
\hline & Camera-observer effect & & $\checkmark$ & $\checkmark$ \\
\hline & Lack of prior knowledge of students & & & $\checkmark$ \\
\hline \multirow[t]{15}{*}{ Controllable } & Not behaving creatively-originally & $\checkmark$ & & \\
\hline & Determining excessive lesson content & $\checkmark$ & $\checkmark$ & \\
\hline & Inadequate individual preparations & $\checkmark$ & & \\
\hline & Loss of motivation & $\checkmark$ & & \\
\hline & Unsystematic workings in the planning process & $\checkmark$ & & \\
\hline & Inadequate planning on concrete materials & $\checkmark$ & $\checkmark$ & $\checkmark$ \\
\hline & Not planning potential situations in detail & $\checkmark$ & $\checkmark$ & $\checkmark$ \\
\hline & Planning extremely difficult questions-problems & $\checkmark$ & & \\
\hline & Not planning time usage in detail & $\checkmark$ & & \\
\hline & Not planning teaching activities in detail & $\checkmark$ & & \\
\hline & Lacking of pre-implementation & $\checkmark$ & & \\
\hline & Not reviewing lesson plan in detail & $\checkmark$ & & \\
\hline & Implementing of lesson plan wrongly-incomplete & $\checkmark$ & & \\
\hline & Working without collaboration & & $\checkmark$ & \\
\hline & Negative motivation (anxiety) of implementer teacher & & $\checkmark$ & \\
\hline
\end{tabular}

1: First study lesson, 2: Second study lesson, 3: Third study lesson

Their attributions focused on unsuccessful teaching situations related to factors that were under their control. There had been a decrease in the number of attributions for the uncontrollable factors in the process. One of the prominent factors among their uncontrollable attributions is camera-observer effect. In the second and third reflection process, they stated that the camera and observers in the class negatively affected the students. Therefore, the students were not able to demonstrate their actual performances in these lessons:

Mina: ...I thought that they failed because they were not able to focus much.

You know people feel anxious in front of the camera, and there were three teachers (group members). Is that why they were not able to focus?

Nuray: Yes, sitting on the front desk affected them (the students) negatively

Nihat: Did it affect them? 
Nuray: Yes

Mina: I sat in the rearmost desk in the previous one [preimplementation], did not I?

Nuray: Yes, you did

Mina: For this reason they may had been comfortable.

Nuray: Yes, many students watched us in this lesson (the $3^{\text {rd }}$ study lesson)

Mina: Yes

Nuray: Many students watched us to understand what we were writing (referring observation notes)...

(Study Lesson III-Reflection Meeting I)

One of the prominent factors among their controllable attributions is planning potential situations. They thought that they did not focus on possible student-teacher responses in the planning processes. Therefore, the implementer teachers failed to give appropriate responses in the chaos moments:

Mina: ...Why did I get so worried? Because, I think, I had difficulty in guiding students, especially in the main activity (focused on solution of first-degree linear equations $[5+\mathrm{a}=12]$ ). I thought the student would subtract five from both sides [of the equation] but did not able to. I panicked at that moment.

Nihat: You panicked. I've said before, the most important weakness of this plan is possible teacher responses

Nuray: Yes...

(Study Lesson II-Reflection Meeting II)

\section{Making Adaptive Inferences}

It was observed that, in the reflection processes, the teachers had similarly produced a wide variety of results for their planning and teaching behaviors. Their inferences in the three reflection processes are presented in Table 3.

Table 3

Teachers' inferences for planning and teaching behaviors

\begin{tabular}{llcc}
\hline Focus & Inferences & 1 & 2 \\
\hline Planning & Behave creatively-originally & $\checkmark$ & \\
& Determine simpler lesson content & $\checkmark$ & $\checkmark$ \\
& Be open to new ideas & $\checkmark$ & \\
Increase individual performance & $\checkmark$ & \\
Plan concrete materials in more detail & $\checkmark$ & \\
Focus on planning main activity & $\checkmark$ & \\
Plan teaching activities in more detail & $\checkmark$ & \\
Determine simpler questions-problems & $\checkmark$ & \\
Conduct a pre-implementation & $\checkmark$ & \multicolumn{2}{c}{$\checkmark$} \\
Write simple and clear sentences in plan & $\checkmark$ & & \\
Plan potential situations in more detail & & & \\
Be more selective to determine materials & &
\end{tabular}




\begin{tabular}{|c|c|c|c|c|}
\hline & $\begin{array}{l}\text { Work in cooperation } \\
\text { Choose a subject that is more compatible with research theme }\end{array}$ & & $\checkmark$ & $\checkmark$ \\
\hline \multirow[t]{7}{*}{ Teaching } & Talk less & $\checkmark$ & $\checkmark$ & $\checkmark$ \\
\hline & Guide and support students in learning & & & \\
\hline & Provide more opportunity for students to talk & & & \\
\hline & Create a discussion environment & $\checkmark$ & $\checkmark$ & \\
\hline & Keep calm during teaching & & $\checkmark$ & $\checkmark$ \\
\hline & Observe yourself and students & & & $\checkmark$ \\
\hline & Use concrete materials & $\checkmark$ & $\checkmark$ & $\checkmark$ \\
\hline
\end{tabular}

One of the prominent inferences about planning behavior is determining simpler lesson content:

Mina: ...In the next planning process, I will always recommend choosing lesson content in the simplest way. [Implementer] teacher do not worry about how I will teach this intense lesson content in 40 minutes. Clear, less, and in essence [lesson content]. Then [implementer] teacher can be more comfortable Nihat: Also, we can observe lesson easier Mina: Yes...

(Study Lesson II-Reflection Meeting II)

Another important inference about planning behavior is behaving creatively-originally. They decided to prepare original teaching materials without being overly committed to internet resources and textbooks in the next planning processes:

Nihat: ...I mean, we must think more originally in the next

Nuray: Yes

Nihat: Let us not get in trouble. I understand that here. For example, instead of searching in the internet, let us prepare our own materials Nihat: Absolutely I agree...

\section{(Study Lesson I-Reflection Meeting I)}

One of the prominent inferences about teaching behavior is using concrete materials. They made a decision to make more benefit from concrete teaching materials in their mathematics class

Nuray: ...I had never thought using [concrete teaching] material would be so effective. Even a very unsuccessful student succeeded drawing the parallelogram in finally.

Nihat: Yes

Nuray: And they were drawing very well on their dotted paper Nihat: As you said, it was not an easy task [for students]

Nuray: Not easy, really. He (the unsuccessful student) examined it (parallelogram) in his own hands [with geometry strips] and saw it on the geometry board. He understood how a parallelogram could be draw systematically. Maybe he did not understand it at first 
Nihat: But he was able to draw it

Nuray: Yes

Nihat: If you talk to him for two hours, maybe you will not be able to create that effect in 5 five minutes (the time of using concrete materials of him)

Nuray: Yes

Nihat: Even if you talk to him for 2 hours, you still cannot be successful

Mina: Absolutely I agree

Nuray: When we teach with old method (lecture method) student

Mina: They (student) learn nothing

Nihat: But we think we are successful, right?

Nuray: We think we are successful but actually, we persuade ourselves

Mina: Yes...

(Study Lesson III-Reflection Meeting II)

When the inferences that they had made throughout the whole process were examined, it was seen that all of them are adaptive. In the three reflective processes, the teachers, similarly, did not make any defensive inferences, which withdrew them from planning activities.

\section{DISCUSSION}

This study focused on a group of teachers' reflection activities on their mathematics teaching practices in a lesson study process. Teachers' reflection activities were defined and analyzed based on the literatures on self-regulation (Pintrich, 2000; Schunk, 2012; Zimmerman, 2000, 2002; Zimmerman \& Schunk, 2004) and teacher regulation (Bembenutty, 2007; Çapa-Aydın et al., 2009; Çapa-Aydın \& Uzuntiryaki-Kondakçı, 2014; Randi, 2004; Taylor, 1994; Yetkin-Özdemir et al., 2014). Teachers' reflection activities were analyzed under three major themes: (i) evaluation, (ii) causal attribution, (iii) inference.

Teachers' evaluation activities were analyzed in terms of scope they focused (i.e., lesson phase, teaching activity) and criteria (i.e., research theme, routine teaching methods/behaviors) they used. The findings indicated that the teachers made holistic and superficial evaluations for the phases (warming up, main, and practicing) of the lessons, and had difficulty in making detailed evaluations based on activity. They preferred to use multiple criteria when they were assessing. Therefore, they defined same lesson phases or teaching activities as successful and unsuccessful. In the planning processes, the teachers might unable to identify clear goals and success criteria. Therefore, they might unable to make focused and detailed observations and collect reliable data about their performance. For this reason, they might unable to obtain the data that will enable them to decide whether they have achieved their goals.

Another important finding is that during the evaluation processes they did not focused on the practicing phases of the lessons. They might not be giving importance to this 
lesson phase. The observations on planning processes indicated that they planned the practicing phases with the aim of filling the time remaining from planning of warming up and main phases. Therefore, they might not need to make an evaluation for this lesson phase.

On the other part, the teachers' causal attribution activities were analyzed in terms of the focus (successful-unsuccessful teaching situations) and controllability (controllable, uncontrollable). The results indicated that the teachers tended to make attribution for failure. They attributed their failures to a variety of factors that are controllable and uncontrollable, but mostly controllable. In addition, they related their failure to the factors that were under their control. Yetkin-Özdemir et al. (2015) similarly observed that novice middle-school mathematics teachers focused on unsuccessful teaching situations in their attribution process, while their attributions of unsuccessful teaching situations were largely uncontrollable. The differences on the characteristics of the participants that is working with novice teachers versus experienced teachers may be one of the reason for the difference observed among the attributions. Additionally, working together as a group in a lesson study context might also led them to focus on the factors that they could control.

The findings also showed that there had been a decrease in their uncontrollable attributions in process. In other words, as they engaged with lesson study activities, the teachers related failure to themselves more. This may be due to the opportunities (e.g., working in collaboration, spending a significant time to reflect on their performances) that lesson study model provide to the teachers. Lesson study allows teachers to design their own instructional materials and lesson plans collaboratively, to implement them in their own classrooms, and evaluate their plans as a group. These lesson study activities might encourage the teachers to attribute the failing aspects of lesson plans that were under their full responsibility to themselves.

The teachers' attributions were closely related to their inferences. In this study, teachers' inference activities were analyzed in terms of the focus (i.e., decisions for plans, decisions of future implementations) and nature (adaptive vs. defensive). The findings showed that the teachers made various a variety of conclusions with regard to their planning activities (i.e., determining simpler lesson content) and teaching behaviors (i.e., keeping calm in the teaching process) in the course of the next research lesson. All inferences observed throughout the lesson study were completely adaptive. In other words, the teachers did not made any defensive inferences. During the reflection processes, the teachers had consistently made constructive-positive inferences to get more effective planning and implementing in the next study lesson process.

Cyclical activities that lesson study includes might had an effect on this result. In this study, in parallel with the original format, the teachers were expected to conduct a new study lesson practice in line with the same research theme (meaningful learning and student centered education) after they had finished their reflection activities. Following the detailed evaluations and causal attributions they had made in a study lesson process, they were able to make important inferences regarding the deficiencies on their planning activities and teaching methods/behaviors. Similarly, it was observed by Kwon and 
Orrill (2007) that video reflection activities that were regularly conducted lead to an increase in adaptive inferences.

\section{CONCLUSION}

In this study, it was concluded that lesson study encourages teachers to conduct reflection activities (evaluation, causal attribution and inference) effectively. Lesson study seems to have the potential in supporting teachers to make detail, comprehensive and reliable evaluations of their teaching, and to make causal attributions and adaptive inferences that are productive for their future teaching tasks. This conclusion is in agreement with the studies of Meyer (2006), Sponsel (2010) and Wright (2009). In these studies, mathematics teachers stated that lesson study encouraged them for selfevaluation (Meyer, 2006; Sponsel, 2010) and led them to make decisions towards improving their teaching by increasing their awareness of their own teaching practices (Meyer, 2006).

However, this study is limited to the findings obtained from three middle school mathematics teachers having had approximately 10 years of professional experience and worked in the central schools in a small province in Turkey. This study was also conducted within a limited time, approximately about 5 months. There is a need for long-term studies including teacher groups with different professional experiences in different educational regions. Reflection activities help teacher to identify their strengths and weaknesses as a math teacher, and contribute them to self-improvement (Zakaria \& Maat, 2010). Through such studies, these important activities and the effects of the lesson study on these activities can be made more understandable.

\section{ACKNOWLEDGEMENTS}

This article is a part of the first author's doctoral dissertation entitled as "Investigation of Middle School Mathematics Teachers' Group-Based Self-Regulation of Instructional Activities in the Context of Lesson Study Model", presented at Hacettepe University Graduate School of Educational Sciences, in 2015.

\section{REFERENCES}

Bembenutty, H. (2007). Teachers' self-efficacy and self-regulation. Academic Exchange Quarterly, 11(1), 155-161.

Creswell, J. W. (2007). Qualitative inquiry and research design: Choosing among five approaches (2. ed.). London: Sage.

Çapa-Aydın, Y., Sungur, S., \& Uzuntiryaki, E. (2009). Teacher self regulation: Examining a multidimensional construct. Educational Psychology, 29(3), 345-356.

Çapa-Aydın, Y., \& Uzuntiryaki-Kondakçı, E. (2014). Öğretmen özdüzenlemesi [Teacher self regulation]. In G. Sakı (Ed.), Öz-düzenleme: Öğrenmeden ögretime özdüzenleme davranışlarının gelişimi, stratejiler ve öneriler [Self-regulation: The development, strategies, and recommendations of self-regulating behaviors in learning and teaching] (pp. 218-230). Ankara: Nobel. 
Doig, B., \& Groves, S. (2011). Japanese Lesson Study: Teacher professional development through communities of inquiry. Mathematics Teacher Education and Development, 13(1), 77-93.

Fernandez, C., \& Yoshida, M. (2004). Lesson Study: A Japanese approach to improving mathematics teaching and learning. New Jersey: Lawrence Erlbaum Associates.

Gabriele, A. J., \& Joram, E. (2007). Teachers' reflections on their reform-based teaching in mathematics: Implications for the development of teacher self-efficacy. Action in Teacher Education, 29(3), 60-74.

Kwon, N. Y., \& Orrill, C. H. (2007). Understanding a teacher's reflections: A case study of a middle school mathematics teacher. School Science and Mathematics, 107(6), 246257.

Lewis, C. (2000, April). Lesson Study: The core of Japanese professional development. Paper presented at the Annual Meeting of the American Educational Research Association (AERA), New Orleans, United States of America.

Lin, X. (2001). Reflective adaptation of a technology artifact: A case study of classroom change. Cognition and Instruction, 19(4), 395-440.

Meyer, R. D. (2006). Lesson Study: The effects on teachers and students in urban middle schools. (Unpublished Doctoral Dissertation 3195279), Baylor University, Texas, United States.

Nathan, M. J., \& Knuth, E. J. (2003). A study of whole classroom mathematical discourse and teacher change. Cognition and Instruction, 21(2), 175-207.

Paris, S. G., \& Winograd, P. (2001). The role of self-regulated learning in contextual teaching: Principles and practices for teacher preparation. Columbus, OH: ERIC.

Pintrich, P. R. (2000). The role of goal orientation in self-regulated learning. In M. Boekaerts, P. R. Pintrich, \& M. Zeidner (Eds.), Handbook of Self-Regulation (pp. 451502). New York: Academic Press.

Randi, J. (2004). Teachers as self-regulated learners. Teachers College Record, 106(9), 1825-1853.

Saito, E. (2012). Key issues of Lesson Study in Japan and the United States: A literature review. Professional Development in Education, 38(5), 777-789.

Schunk, D. H. (2001). Social cognitive theory and self-regulated learning. In B. J. Zimmerman \& D. H. Schunk (Eds.), Self-Regulated Learning and Academic Achievement: Theoretical Perspectives (2nd ed., pp. 125-152). Mahwah, NJ: Lawrence Erlbaum Associates. 
Schunk, D. H. (2012). Learning theories: An educational perspective (6th ed.). Boston, MA: Pearson Education.

Simon, M. A. (1995). Reconstructing mathematics pedagogy from a constructivist perspective. Journal for Research in Mathematics Education, 26, 114-145.

Sponsel, B. J. (2010). The impact of the infinite mathematics project on teachers' knowledge and teaching practice: A case study of a title IIB MSP professional development initiative. (Unpublished Doctoral Dissertation 3438642), Kansas State University, Kansas, United States.

Stepanek, J. (2001). A new view of professional development. Northwest Teacher, 2(2), 2-6.

Stepanek, J., Appel, G., Leong, M., Mangan, M. T., \& Mitchell, M. (2007). Leading Lesson Study: A practical guide for teachers and facilitators. California: Corwin Press.

Takahashi, A., \& Yoshida, M. (2004). Ideas for establishing Lesson-Study communities. Teaching Children Mathematics, 10(9), 436-443.

Taylor, L. (1994). Reflecting on teaching: The benefits of self-evaluation. Assessment \& Evaluation in Higher Education, 19(2), 109-122.

Tursini, U. (2012, November). Researching teacher self-evaluation practices of college english teachers in Indonesia. Paper presented at the 5th International Conference of Education, Research and Innovation, Madrid, Spain.

Weiner, B. (1985). An attributional theory of achievement motivation and emotion. Psychological Review, 92(4), 548.

Wright, T. D. (2009). Investigating teachers' perspectives on the impact of the Lesson Study process on their mathematical content knowledge, pedagogical knowledge, and the potential for student achievement. (Unpublished Doctoral Dissertation 3361223), University of New Orleans, Louisiana, United States.

Yetkin-Özdemir, İ. E., Gürel, R., Akdal, P., \& Bozkurt, E. (2014). Öğretmenlerde özdüzenleme: Matematik dersi örneği [Teacher self-regulation: A case of math lesson]. In G. Sakız (Ed.), Öz-düzenleme: Ö̆grenmeden öğretime öz-düzenleme davranışlarının gelişimi, stratejiler ve öneriler [Self-regulation: The development, strategies, and recommendations of self-regulating behaviors in learning and teaching] (pp. 233-247). Ankara: Nobel.

Yetkin-Özdemir, İ. E., Gürel, R., Bozkurt, E., \& Akdal, P. (2015, June). Göreve yeni başlayan ortaokul matematik ögretmenlerinin nedensel yüklemeleri [Causal attribution of novice middle-school mathematics teachers]. Paper presented at the 2nd Eurasian Educational Research Congress, Ankara, Turkey.

Yin, R. K. (2003). Case study research: Design and methods (3rd ed.). London: Sage. 
Yoshida, M. (1999). Lesson Study: A case study of a Japanese approach to improving instruction through school-based teacher development. (Unpublished Doctoral Dissertation), The University of Chicago, Illinois, United States.

Zakaria, E., \& Maat, S. M. B. (2010). An exploration of mathematics teachers' reflection on their teaching practices. Asian Social Science, 6(5), 147-152.

Zimmerman, B. J. (2000). Attaining self-regulation: A social cognitive perspective. In M. Boekaerts, P. R. Pintrich, \& M. Zeidner (Eds.), Handbook of Self-Regulation (pp. 13-39). New York: Academic Press.

Zimmerman, B. J. (2002). Becoming a self-regulated learner: An overview. Theory into Practice, 41(2), 64-70.

Zimmerman, B. J., \& Schunk, D. H. (2004). Self-regulating intellectual processes and outcomes: A social cognitive perspective. In D. Y. Dai \& R. J. Stenberg (Eds.), Motivation, Emotion, and Cognition: Integrative Perspectives on Intellectual Functioning and Development (pp. 323-349). NJ: Erlbaum. 